\title{
Jam częścią tej siły, która przyszłości pragnąc, wiecznie w przeszłość zerka'. Nostalgiczne źródła socjalizmu we wczesnych pracach Stanisława Brzozowskiego
}

I am a part of that power which eternally wills future and eternally glances into the past: Nostalgia as a source of socialism in early Stanislaw Brzozowski's texts

DOI: $10.12775 /$ LL.3.2021.002 | CC BY-ND 4.0

ABSTRACT: In order to understand the endurance of memory of socialism, it is necessary to conduct an analysis of the beginning of the socialist thought in Poland. In the article, the mechanisms of socialism origin in early Stanislaw Brzozowski's texts are reconstructed. The analysis has been conducted within the context of prospective nostalgia, the experience of modernity, and the history of ideas.

KEYWORDS: prospective nostalgia, socialism, Stanislaw Brzozowski, modernity

1 Parafraza zdania wypowiedzianego przez Mefisto w Fauście Johanna Wolfganga von Goethego: „Ja jestem częścią owej siły, której władza / pragnie zło zawsze czynić, a dobro sprowadza” (1926: 173). 


\section{Brzemię nowoczesności}

Dzieje początków postsocjalistycznej nostalgii powinny objąć pomijany dotychczas okres, w którym materializm dialektyczny przestawał być wyłącznie teoria poznawczą, a zaczął stawać się sposobem praktykowania życia codziennego. Niepodobna bowiem uchwycić mechanizmów nim rządzących, nie uwzględniwszy szerszego kontekstu, z jakiego socjalizm wziął swe początki. Związać go zaś można z doświadczeniem nowoczesności, które dążąc do gwałtownego obalenia wszelkich, znanych dotychczas wartości (Berman 2006: 36) czy też „«racjonalnej kosmologii», która leżała u podstaw mieszczańskiego przekonania o uporządkowanych stosunkach czasu i przestrzeni” (Bell 1998: 22), nie powoływało do istnienia nowego świata. Oto więc nowoczesny człowiek znalazł siebie w nieoczekiwanej zawierusze „bezustannych wstrząsów ogarniających całość życia” (Marks, Engels 1981: 346), ustawicznych przemian i niepewności potegowanej gwałtownym rozkładem znanych z dawien dawna stosunków społecznych. Upragniona wolność, gwarantowana przez świat nowoczesny, stała się zatem nie błogosławieństwem, lecz brzemieniem, które - chcąc nie chcąc - człowiek był zmuszony dźwigać. I właśnie ten przymus - przymus wolności, zapoczątkowany przez dynamiczny ruch nowego świata - przesądził o żywotności socjalizmu zarówno u zarania, jak i u jego schyłku.

W tym zwrotnym punkcie historii urodzenie przestało determinować stosunki społeczne. Jednostka została przeto zmuszona, „by sama siebie zachować, podważyć, wybawić [...], stworzyć własne prawodawstwo” (Nietzsche 2001: 202). Wolność, od której nie sposób uciec, zaczęła się jawić jako przymus - antynomia samej siebie. Próbując zrozumieć istotę reperkusji wywołanych przez przymus wolności, nie sposób nie odnieść się do momentu dziejowego. Początek XX w. był okresem znamiennym, w którym echa przemian nowoczesnych dochodziły już do głosu, jednak wtórowało im równocześnie wspomnienie niegdysiejszego, szlacheckiego ładu. I właśnie w owym wewnętrznym rozdarciu, „poczuciu jednoczesnego zamieszkiwania dwóch światów” (Berman 2006: 17), upatruję źródeł nostalgii za „starymi dobrymi czasami” i socjalizmu, będącego zaspokojeniem płynącej z niej potrzeby bezpieczeństwa.

Podobną funkcję przypisuje nostalgii Svetlana Boym, rosyjska slawistka, dostrzegając w niej „mechanizm obronny w epoce przyspieszonego rytmu życia oraz wstrząsów historii” wypływający z „pragnienia ciągłości w pofragmentowanym świecie” (Boym 2001: XIV). W odróżnieniu od niej nie chciałabym jednak wiązać nostalgii z okresem lokującym się wyłącznie w czasie minionym. Proponuję zatem rozszerzenie dotychczasowych ram interpretacyjnych nostalgii w sposób ahistoryczny i ahierarchiczny. Ahistoryczność ujęcia miałaby polegać na włączeniu w zakres treściowy pojęcia szerokiego spektrum zjawisk nostalgicznych rozumianych jako szczególnego rodzaju postawa wobec teraźniejszości, wywołana afektywnym przywiązaniem do tak zwanego „gdzie indziej” (Bauman 2018: 11), nawet gdyby owo „gdzie indziej” nie pozostawało w związku z czasem faktycznym, a sytuowało się w nakierowanym na przyszłość czasie 
wyobrażonym. Ahierarchiczność natomiast zasadzałaby się na rozróżnieniu podtypów nostalgii na retrospektywną i prospektywną̧2. Ujęcie to daje asumpt do rozpatrywania nostalgii zarówno w odniesieniu do przeszłości, jak i przyszłości. Zasadniczo dopuszczalne jest również równoległe zaistnienie obu rodzajów nostalgii. Wszak nie jest niemożliwe, by doświadczać tego, co już było, i ową wizję rzutować w przyszłość.

\section{Nostalgia retrospektywna i prospektywna}

Mianem nostalgii retrospektywnej określać będę tedy przywiązanie do owego "gdzie indziej” sytuującego się w przeżytym doświadczeniu. Tak pojmowana nostalgia obejmuje jednak na ogół nie konkretną przestrzeń - miejsce bezpowrotnie utracone - lecz wiążące się z nią doświadczenie. Marek Zaleski, kreśląc traktat o Formach pamięci, nie bez słuszności stwierdzi, że „tęskni się nie tyle za miejscem utraconym, ile za sobą dawnym w tym miejscu” (1996: 16). Żywotność tęsknoty podtrzymywana jest przez niepewność świata nowoczesnego. Im bardziej w przeżyciu nostalgika owa niepewność będzie namacalna, tym chętniej będzie on się oddawał studiowaniu przeszłości. Paradoksalnie to za jej sprawą rzeczywistość zyskuje stabilizację. Kiedy „wszystko, co stałe, rozpływa się w powietrzu" (Marks, Engels 1981: 346), jedynym bodaj pewnikiem staje się to, co przynależne historii. O ile bowiem teraźniejszość i przyszłość podlegają dynamice ustawicznych przemian, o tyle atrybutem przeszłości jest stabilność ${ }^{3}$. Eksplorowanie czasu minionego zaspokaja wobec tego podstawową potrzebę bezpieczeństwa, co przesądza o żywotności nostalgii zwłaszcza w tych społeczeństwach, które podlegać miały nagłym i nieoczekiwanym przemianom ekonomicznym, religijnym czy też politycznym. Podług tego geneza nostalgii retrospektywnej mieć będzie negatywny punkt wyjścia (por. Czapliński 1999; Burszta 1997), ponieważ za impuls zwracający ku dawności uznać należy poczucie nieprzynależności do czasu aktualnego bądź postrzeganie go jako niekompletnego (Burszta 1997: 124). Wskazane źródło przeżycia nostalgicznego jest częścią wspólną nostalgii retrospektywnej i prospektywnej.

2 Pewne wątpliwości budzić może określenie proponowanego podejścia jako ahistorycznego i ahierarchicznego, zawłaszcza jeżeli nostalgię rozpatruję jako kategorię nadrzędną wobec dwóch jej podtypów (nostalgii retrospektywnej i prospektywnej), zaś podstawą dyferencyjną czynię odniesienie czasowe. Pragnę przeto zaznaczyć, że realizacja ahistoryczności znajduje odzwierciedlenie w ogólnej konceptualizacji nostalgii, rozumianej jako przywiązanie do szeroko zakreślonego „gdzie indziej” bez ściśle wyznaczonego horyzontu czasowego, jakiego owo „gdzie indziej” miałoby dotyczyć. Ahierarchiczność wpisuję z kolei w treść samych podtypów, co do których w miejsce „albo-albo” podstawiam „zarówno-jak”.

3 Dyskusyjna może być w tym miejscu kwestia mimesis, niewątpliwie związanego z procesem rekonstruowania przeszłości, która to przeszłość w przeżyciu nostalgicznym ulega idealizacji (por. Czapliński 1999). Stwierdzając jednak, że atrybutem przeszłości jest stabilność, odnoszę się do samego tematu - minionych zdarzeń, przedmiotów czy ludzi - wyznaczającego horyzont aktywności wspomnieniowej nostalgika. W tej perspektywie skończoność przeszłości staje się gwarantem stabilności. Nie sposób zakwestionować istnienia owych znaków, konstytuujących $\mathrm{w}$ istocie curriculum vitae jednostki. 
Abstrahując nieco od miejsc wspólnych, swoistość nostalgii prospektywnej4 manifestuje się w sposób podwójny. Bierze ona swój początek w tęsknocie za niegdysiejszym uporządkowaniem, aczkolwiek - w odróżnieniu od jej bliźniaczej odmiany - ukierunkowuje aktywność podmiotu ku czasowi przyszłemu. Prawdziwa linia demarkacyjna przebiega jednak nieco dalej, a mianowicie w ukształtowaniu postawy nostalgika wobec otaczającej go rzeczywistości. O ile bowiem za figurę nostalgii w retrospektywnej odmianie uznać należy bierność, a dokładniej zawłaszczenie aktywności poznawczej przez nawracające reminiscencje i wiążące się $\mathrm{z}$ nimi redefiniowanie historii, to domeną nostalgii prospektywnej staje się szeroko rozumiany czyn wyrażający się nie tyle w podejmowanych próbach resuscytacji dawności, co raczej w staraniach o usensownienie otaczającego świata, które rozumiane jest jako przywrócenie poczucia jego zrozumiałości i wiarygodności. Wbrew początkowym intuicjom nie idzie tu bowiem o rekonstrukcję konkretnej rzeczywistości społecznej, od której postawa nostalgiczna bierze swój początek, lecz o stworzenie rzeczywistości zupełnie nowej, zdolnej jednakże odtworzyć ów afekt wsparty na wrażeniu uporządkowania, przewidywalności i ciągłości.

Wypada zauważyć, że choć warunkiem sine qua non obu rodzajów nostalgii jest krytycyzm wobec teraźniejszości, to zrodzone przez nie relacje są właściwie zupełnie różne. Otóż nostalgia retrospektywna, biorąc za punkt wyjścia czas aktualny, zwraca się ku dawności, podsycana zaś jest przez sam wysiłek uobecniania tego, co nieobecne (Zaleski 1996). Nie ma ona jednak na celu rzeczywistego przywrócenia owej nieobecności. Przemysław Czapliński powiada, że nostalgik „cofnięty do wymarzonej przeszłości, umarłby z tęsknoty za tęsknotą" (1999: 64) i to w istocie stanowi o odrębności nostalgii prospektywnej, której istotą nie jest samo przeżywanie dawności, lecz dążenie do ekspresji afektu przez nią wywoływanego. Chociaż kontekst powstania - niezgoda na teraźniejszość i zwrot ku czasowi minionemu, stanowiącemu wobec niej kontrast - jawi się jako analogiczny, to mechanizmy nią rządzące przedstawiają się zgoła odmiennie. Nostalgik tego rodzaju nie poprzestanie na przejawianiu czołobitności wobec historii, gdyż nie jest dla niego ona celem, a zaledwie przyczynkiem do dalszej aktywności. Wprawdzie będzie się względem niej ustosunkowywał, uznając za miarę swych dążeń, lecz stosunek ten pozbawiony będzie bezwzględnej gloryfikacji. Przeszłość spełni więc funkcję ledwie użytkową, a jej użytkownik sięgnie po nią wtenczas, kiedy będzie chciał się upewnić, że stworzona przezeń wizja przyszłości faktycznie odtwarza doznawane niegdyś poczucie pełni i przewidywalności. Wypada podkreślić, że związek nostalgii prospektywnej z przeszłością nie implikuje pragnienia ponownego jej doświadczenia, a jedynie chęć doznania afektów przez nią wywoływanych, zatem stwarzana w oparciu o nią wizja przyszłości może diametralnie wykluczać pewne

4 Wypada w tym miejscu zauważyć, że termin: „nostalgia prospektywna” nie stanowi novum w literaturze naukowej. Pojęcie to pojawia się u Svetlany Boym, która wskazuje jednak na nieco inną jego denotację niż ta, zaproponowana w niniejszym artykule (por. Boym 2019). 
elementy dawnej rzeczywistości, uznawszy je za wadliwe bądź niedostosowane do obecnych warunków. $\mathrm{W}$ tej perspektywie nostalgia prospektywna jawi się jako pragnienie uczestniczenia i czynnego kreowania nowoczesnego świata, natomiast nostalgia retrospektywna zdaje się go odrzucać.

\section{Biograficzne potępienie}

Rok 1989 miał okazać się ważnym momentem nie tylko w perspektywie historii społecznej, lecz również w recepcji twórczości Stanisława Brzozowskiego. Wtenczas do obiegu anglojęzycznego włączona została książka Stanisław Brzozowski and the Polish Beginnings of „Western Marxism” pióra Andrzeja Walickiego, wskazująca na autora Płomieni jako „pioniera, a zarazem najbardziej radykalnego przedstawiciela” tzw. zachodniego marksizmu, który - z racji nikłej znajomości spuścizny Brzozowskiego na Zachodzie - niesłusznie był wiązany z nazwiskami György'ego Lukácsa i Antonio Gramsciego (Walicki 2011: 366). Publikacja ta, zaklasyfikowana jednak jako dotycząca polskiego komunizmu, stanęła na półkach księgarń i bibliotek tuż obok prac o Bolesławie Bierucie i Nikołaju Bucharinie. Przepowiedziane blisko 80 lat wcześniej „biograficzne potepienie” (Brzozowski 1913: 118, zob. Wyka 2012: 162 i nast.) objawiło się zatem po trzykroć. W 1989 r. marksizm przeżywał kryzys nie tylko w krajach ZSRR, ale również w zachodnich ośrodkach akademickich. Tym samym prekursorska - przynajmniej w zamierzeniach - książka Walickiego nie miała większych szans na znalezienie czytelników. Ponadto, włączenie jej w obieg jako pozycji traktującej o komunizmie - nie zaś o marksizmie - przyczyniło się do niesłusznego odczytywania jej w kontekście stricte politycznym.

Przywołałam wzmiankę o „biograficznym potępieniu” nie po to, aby wskazać na niedocenienie autora Płomieni, lecz aby zasygnalizować doświadczenie mnogości rozmaitych idei łączące pokolenie początku i końca XX w.. Nie jest moim zamiarem odszyfrowanie „duchowych połączeń, przeżyć” (Brzozowski 1912: 278), gdyż zabieg ten niewiele powiedziałby o dynamice przemian rządzących ówczesnymi umysłami. Zastosowanie liczby mnogiej nie jest tu przypadkowe. Próżno szukać jednakiego doświadczenia nowoczesności, jak więc odnaleźć jeden typ umysłowości przezeń ukształtowany? Wszak „wszystko [...] jest w nas różne, wielorakie, niewspółmierne; wszystko, co ziemskie różniczkuje nas i rozdziela” (Brzozowski 1912: 366), lecz i „zróżniczkowanie” nie jest stałe. Brzozowski stwierdzi, że nawet „istota człowieka, najgłębsza prawda o nim nie są rzeczą zamkniętą i daną, lecz tworzą się i przeistaczają" (Brzozowski 1912: 364). Wszelkie poszukiwania typu umysłowości XX-wiecznej są bezcelowe. Możliwe jest, co prawda, znalezienie jakiegoś wspólnego mianownika mówiącego coś o każdym, jednak takie podejście byłoby chybione - o nikim nie powiedziałoby wszystkiego. Ażeby choć częściowo uchwycić „niesłychanie zróżniczkowaną i złożoną duszę nowoczesną, z jej nigdy nie znanymi dotąd kryzysami, walkami wewnętrznymi” (Brzozowski 1988: 157), zajmę się człowiekiem nowoczesnym w momencie „stawania się". 
Szkic ten będzie próbą wstępnego zarysowania „walk wewnętrznych” w teoretyczno-filozoficznej biografii Stanisława Brzozowskiego. O zamyśle stworzenia artykułu, stanowiącego całościowe spojrzenie na „dzieje pewnego umysłu”, autor Płomieni donosił Ostapowi Ortwinowi w liście z początku września $1909 \mathrm{r}$. (Brzozowski 197ob: 221). Przedstawiony w dość ogólnym zarysie projekt miał, co prawda, „zreasumować całą publikację”, lecz szczególne miejsce zdawał się on wyznaczać wczesnym tekstom, będącym świadectwem intensywnych poszukiwań intelektualnych i ich wpływów na kształt tworzonej filozofii. Autor wyodrębnił je zresztą z „całości”, dopowiadając, że za sprawą intelektualnej autobiografii będzie mógł „wreszcie [...] usprawiedliwić przedruki starych artykułów” (Brzozowski 197ob: 221). Próby skreślenia „dziejów pewnego umysłu” pokazały jednak, że ogół rozważań nie zmieściłby się w artykule, a rozrósłby się w „wielki tom, trudny do napisania” (Brzozowski 197ob: 396). Projekt całościowy ostatecznie więc został zarzucony ${ }^{5}$ Zachowały się po nim jedynie ślady; wydany rok po śmierci Brzozowskiego drugi tom Idei, noszący tytuł Głosy wśród nocy, zawiera siedem z planowanych 16 części studium (zob. Brzozowski 1970b: 396), pozostałe zaś nigdy nie zostały napisane. W Głosach wśród nocy próżno jednak doszukiwać się świadectwa wczesnych inspiracji. Traktują one o „ciepłych, świeżych jeszcze przeżyciach duchowych” (Ortwin 1912: XX), gdyż - jak sam autor zaręczał - „jest rzeczą zawsze najmilszą pisać o rzeczach, które mnie samego niedawno poruszyły” (Brzozowski 197ob: 348). Od najwcześniejszych swych duchowych mistrzów zaczął się oddalać ponad rok przed ukończeniem publikacji. „O Marksie myślę z rozpaczą, bo coraz dalej jestem od niego” (Brzozowski 1970b: 248) - napisze w 1909 r. do Salomei Perlmutter - i pomimo że tuż przed śmiercią stwierdzi, iż w jego katolicyzmie pozostało wiele $\mathrm{z}$ marksizmu oraz wszelkich innych „izmów” (Brzozowski 1970b: 592-599), wytyczenie „dziejów pewnego umysłu” nigdy nie było mu dane.

\section{Klimat umysłowy w Polsce}

Nie sposób uchwycić owych dziejów bez - choćby pobieżnej - rekonstrukcji „klimatu umysłowego w Polsce” (Brzozowski 197ob: 237), który nie tylko trwale zaważył na całokształcie filozofii Brzozowskiego, lecz był też stałym punktem odniesienia dla pierwszych prac krytycznych. „Wszystko stało się grozą, rozpaczą i lękiem" - napisze w młodzieńczej recenzji dramatu Przybyszewskiego (Brzozowski 1988: 536), choć do opisania doświadczenia Brzozowskiego należałoby raczej użyć czasu teraźniejszego. Prześledzenie biografii podpowiada bowiem, że innego stanu właściwie nie doświadczył. Andrzej Mencwel wskazuje wręcz, że kryzys jest zasadniczą nicią kształtowania się jego osobowości pisarskiej

5 W liście do Ostapa Ortwina z 14 kwietnia 1910 r. (Brzozowski 197ob: 396) Brzozowski zaproponował 16 części, z których składać się miały „Dzieje pewnego umysłu”. Ostatecznie siedem z nich zostało spisanych i weszło w skład drugiego tomu Głosów wśród nocy. Pod nieco zmienionym tytułem („Kilka uwag o współczesnej literaturze”) zachował się również częściowo fragment pracy „O obecnym stanie literatury polskiej” mającej być pierwotnie zakończeniem autobiografii (zob. Brzozowski 197ob: 396-397). 
(1988: 7). Już sam fakt urodzenia i wychowania się w „wysadzonej z siodła” rodzinie szlacheckiej świadczyć może o słuszności tej diagnozy. Jeżeli przywołać jeszcze moment dziejowy, doświadczenie kryzysu sytuuje się w dwóch wymiarach: osobistym i historycznym (Mencwel 1988). Należy przy tym zaznaczyć, że o ile faktycznie kryzys był centralnym elementem w biografii Brzozowskiego, o tyle sam Brzozowski miał również pojęcie o niegdysiejszym porządku dawnej Rzeczypospolitej. Został przecież wychowany w etosie szlacheckim, uznającym tradycję za jedyną obowiązującą rację (zob. Mencwel 2014), wobec czego rodząca się nowoczesność wraz ze społecznymi przemianami zyskiwała miano chwilowej mody, po ustąpieniu której świat zyskałby na powrót niegdysiejszy ład.

Na takim więc gruncie wzrastać miała myśl Stanisława Brzozowskiego. Dróg jej rozwoju nie wytyczała jednak bierność nostalgii w retrospektywnej odmianie. Twórczość filozofa nie rodziła się bowiem z pragnienia restauracji szlacheckiego porządku, który - trzeba to wyraźnie zaznaczyć - nie miał podstaw $\mathrm{w}$ faktycznym doświadczeniu, lecz jedynie w pewnych wyobrażeniach. Przełom XIX i XX w. w istocie był okresem przejściowym między szlacheckimi dworkami rodem z Pana Tadeusza a nowym społeczeństwem (zob. Urbanowski 2017). Skądinąd, znacząca część studiów nad twórczością Brzozowskiego poświęcona została jego umiejscowieniu na mapie nowoczesnego świata (Markowski 2007; Burek 1972; Urbanowski 2017; Wyka 2012). Postać omawianego tu autora wymykała się jednak jednoznacznym konceptualizacjom: o ile bowiem głoszonym przez niego poglądom filozoficznym można przypisać miano rewolucyjnych, o tyle podobna kategoryzacja samego pisarza budzi większe zastrzeżenia. $\mathrm{W}$ istocie postępowość $\mathrm{w}$ wymiarze biograficznym nie zasadzała się na pragnieniu nastania nowego świata, lecz wytłumaczeniu samych mechanizmów przemian. Była ona zatem „nowoczesnością wbrew sobie” (Compagnon 2005: 7), wynikającą nie z samych zapatrywań, a z doświadczenia sytuacji przejścia, wobec której odczuwał on naglącą potrzebę wytłumaczenia nowej rzeczywistości i poprzez to uczynienia jej na powrót bezpieczną. Zasadniczo, podzielał on przeświadczenie o tym, że „wszystko, co stałe, rozpływa się w powietrzu”, ale na samej konstatacji zmienności nie był w stanie pozostać. Myśl Brzozowskiego napędzało $\mathrm{w}$ istocie pragnienie znalezienia zasady owej zmienności, co zbliża go istotnie do tradycyjnego, nie zaś postępowego świata. Kwintesencji jego sposobu ujmowania nowoczesności byłabym zatem skłonna dopatrywać się nie w czasie przyszłym, lecz w czasie minionym.

Podobnie zapatrywała się na tę kwestię Józefa Kodisowa, uczennica Richarda Avenariusa, sugerująca, że „uczuciowe głębie jego [Brzozowskiego] istoty należą do epoki przeszłej. Stamtąd pozostała potrzeba absolutu i rozpacz nad tym, że go nigdzie znaleźć nie można" (Kodisowa 1903: 388). Pomimo iż diagnoza ta została postawiona u zarania aktywności pisarskiej Brzozowskiego, odnieść ją można do całokształtu twórczości. Pozostałości szlacheckiego dziedzictwa odnaleźć można u podstaw wszelkich działań nakierowanych na znalezienie formuły nowoczesności. Wewnętrzny nakaz ustanawiania w świecie porządku, 
znajdujący odzwierciedlenie w szeroko zakrojonych poszukiwaniach formuły nowoczesności, wywiedziony został przecież z tradycyjnego ładu, w jakim został wychowany. Znamienne, że Brzozowski w pewien sposób zdawał sobie z tego sprawę i determinizm ten próbował zwalczyć, podejmując się zadania wychowania siebie na nawo za pośrednictwem lektur (zob. Brzozowski 1912: 238 i nast.), co miało dać mu sposobność „wejścia w samo centrum życia” (Brzozowski 1970a: 173). „Ja skończyłem swoje własne wychowanie” - doniesie w lipcu 1909 r. w liście do Szalitów (Brzozowski 1970b: 173) - chociaż o zakończeniu procesu trudno wyrokować. „Czuję, że nie mogę dzisiaj mówić o wynikach całej tej pracy wewnętrznej” (Brzozowski 197ob: 191) - dopowie niecały miesiąc później.

Abstrahując od poczucia niedokończoności projektu antropologicznego, należy pochylić się nad teleologią i metodą procesu „własnego wychowania”. Zakreślona perspektywa przygotowania do rozpoczęcia życia stricte nowoczesnego, w którym Brzozowski nie byłby już ,istotnie piątym kołem w Polsce, przynajmniej postępowej” (Brzozowski 197ob: 436), nie mówi zbyt wiele. Znacznie więcej wyczytać można z krótkiego komentarza do nadesłanej Walentynie i Edmundowi Szalitom syntezy myśli: „Dziś mniej więcej zlało się to wszystko w jedno religijne stanowisko i zdaje się, że będę mógł iść naprzód całą płaszczyzną duszy” (Brzozowski 197ob: 172). Istotą poszukiwań było więc stworzenie nowej wiary, „jednego religijnego stanowiska”, ustanawiającej porządek rodzącej się nowoczesności, a zarazem nadającej mu znaczenie. Wobec tego myśl napędzana była nie przez przyszłość, lecz przez „potrzebę absolutu” zrośniętą z przeszłością. W gruncie rzeczy manifestacji owej potrzeby doszukać się można również i w obranej przez Brzozowskiego metodzie „własnego wychowania”. Mnogość rozmaitych idei - stan nadmiaru, jak określa to zjawisko Marta Wyka (2012) - służyć miała stworzeniu syntezy, stanowiącej jedną prawdę.

\section{W co my mamy wierzyć?}

Stosunek Stanisława Brzozowskiego do nowoczesności był dalece ambiwalentny. Miał świadomość, że oto „zaczyna się nowa epoka w dziejach ludzkości” (Brzozowski 1906: 190), która zrywa z dotychczasowym porządkiem, opierającym się o „konieczność ciążącą z zewnątrz” (Brzozowski 1906: 195). Dostrzegał też naglącą potrzebę dokonania „skoku z królestwa konieczności w dziedzinę swobody” (Brzozowski 1906: 195) i z niecierpliwością wypatrywał momentu, w którym społeczeństwo polskie owego skoku dokona (zob. Brzozowski 1970a: 104). Wprawdzie Brzozowski był myślicielem nowoczesności, lecz nie był myślicielem nowoczesnym. Rozróżnienie to lokuję w perspektywie biograficznej. Wobec tego uznaje go za myśliciela nowoczesności, gdyż całość swych wysiłków ukierunkował na znalezienie jej formuły. Nie sądzę jednak, żeby był myślicielem nowoczesnym - przynajmniej nie w zupełności - ponieważ doświadczanie nowego świata przepojone było w gruncie rzeczy habitusem przednowoczesnym, którego - pomimo podejmowanych prób „własnego wychowania” - nie był w stanie się wyzbyć. Poddawał więc srogiej krytyce szlachecką rzeczywistość, 
dostrzegając jej anachroniczność względem nowoczesności, a jednocześnie wspominał z nostalgią związane z nią poczucie zrozumienia, ładu i przewidywalności (Brzozowski 1970a, 197ob).

„W co wy wierzycie?” - zapyta Brzozowski w manifeście programowym My młodzi (1988: 55-61). Pytanie to, skierowane, co prawda, do dawnych pokoleń, za punkt odniesienia obiera szerszy kontekst, a mianowicie kondycję całego pokolenia, którego reprezentantem był filozof. Tragizm, znamionujący tę kondycję, wynikał z nieadekwatności dawnej wiary do rodzącej się nowoczesności. Pytanie należałoby więc nieco przeformułować: „W co my mamy wierzyć?” o to, w istocie, zapytuje Brzozowski. Odpowiedzi nie usłyszy. Nie zdumiewa to, gdyż wiara nowoczesna musiała „wyeliminować władze pojęć, abstrakcji nad konkretnymi duchowymi procesami” (Brzozowski 197ob: 169). Nowa religia zatem jeszcze nie istniała, należało ją dopiero stworzyć - zadania tego podjął się Stanisław Brzozowski.

Nie ulega wątpliwości, że u początków „dziejów pewnego umysłu” to socjalizm stał się dla niego synonimem nowej wiary ${ }^{6}$. Określenie to, stosowane zresztą przez samego pisarza, znakomicie oddaje funkcje, jaką miał pełnić dla niego w pewnym momencie. Zadaniem wiary - czy też religii - jest tłumaczenie rzeczywistości, dzięki czemu to, co niepojęte, staje się zrozumiałe. W dawnej Polsce wyjaśniano podział na chłopów i szlachtę, odwołując się do odwiecznej nierówności zapisanej na kartach Biblii (Leszczyński 2020). Wówczas wyjaśnienie to było w pełni racjonalne, a za sprawą względnej niezmienności i przewidywalności ówczesnej kultury stanowiło, paradoksalnie, źródło bezpieczeństwa. Nowoczesność doprowadziła jednak do rozkładu przedprzemysłowego, „naturalnego" porządku (Bauman 2010: 31), co rychło uczynić miało świat obcym, nieoswojonym, a wobec tego zagrażającym. Wobec takiego świata lęk odczuwać musiał także Stanisław Brzozowski (Urbanowski 2017; Wyka 2012). Jedynym remedium służącym odbudowie poczucia bezpieczeństwa było więc stworzenie nowej wiary, którą autor Płomieni rozpoznał w socjalizmie. Jego zdaniem „socjalizm nie jest doktryną abstrakcyjną, urzeczywistnianą w historycznej próżni” (Brzozowski 1906: 1), co czynić miało z niego religię na wskroś nowoczesną. Za podstawe obierał on bowiem namacalną, empirycznie dostępną i aktualnie stającą się rzeczywistość. Od niego uzależniał więc Brzozowski wkroczenie Polski w nową epokę: „,zy też rzeczywiście wypadnie już nam widzieć nowy świat, czy też będziemy całe życie tylko pasażerami objeżdżającymi cuda nie przez nas stworzone?" (Brzozowski 1970a: 104).

6 Wszelkie próby włączenia postaci Stanisława Brzozowskiego w ramy socjalizmu są niezwykle trudne. Wynika to nie tylko z mnogości definicji socjalizmu pojawiających się na przestrzeni lat w humanistyce, lecz przede wszystkim z fluktuacji, jakim pojęcie to podlegało w pismach Brzozowskiego. I tak socjalizm opisywany w korespondencji do Wuli i Rafała Burberów w 1907 r. (Brzozowski 197ob: 312-316) będzie zupełnie innym socjalizmem niż ten, do którego odwoła się w 1910 r. (Brzozowski 197ob: 476-477). Z uwagi na to socjalizm będę ujmować jako zjawisko teoriopoznawcze - szerzej opisuję to w dalszych partiach tekstu. 


\section{Socjalizm religią nowoczesności}

Nie jest zatem zaskakujące, że tuż po wojnie, w 1945 r., Stanisław Brzozowski został powołany na patrona nowych czasów (Rams 2017: 35). Ówczesny klimat społeczno-polityczny nie sprzyjał jednak rudymentarnej recepcji socjalizmu filozofa, nawet jeśli - jak pokazują „dzieje pewnego umysłu” - podlegała ona nieustannym przemianom i redefinicjom. Fakt ten nie tylko znacząco utrudniał pełną rekonstrukcje stanowiska wobec socjalizmu, ale tworzył sposobność do dokonywania uproszczeń interpretacyjnych. W twórczości Brzozowskiego doszukiwano się zatem zaczątków komunizmu i myśli lewicowej w Polsce, nawet jeśli jego pismom daleko było do takich idei (Rams 2017: 41). Pojawiające się wówczas głosy (Rams 2017) nie tylko przyczyniły się do ujednoznacznienia myśli Brzozowskiego, lecz włączały ją w krąg dyskusji politycznych, od których sam autor pragnął się odżegnywać, uznając socjalizm za koncepcję teoriopoznawczą (Brzozowski 197ob). Już w 1906 r. zwrócił on zresztą uwagę na przesunięcie w denotacji terminu:

U nas byle się „uważać za socjaliste” - wolno nie mieć najelementarniejszych pojęć o budowie i życiu nowoczesnych społeczeństw; byle mieć „dobre intencje”, wolno mieć w głowie kaszę i kaszą tą żywić i tak chore na wodę w głowie społeczeństwo (1970b: 176).

Według filozofa socjalizm był koncepcją teoriopoznawczą, porządkującą i wyjaśniającą nowoczesny świat, dlatego z tak wielką niechęcią odnosił się do utożsamiania go wyłącznie ze zrywami rewolucyjnymi. Socjalizm miał stać się dla niego religią nowoczesności, która - po raz pierwszy bodaj w dziejach historii idei - zdjąć miała niewolnicze kajdany, które zarzuciło na człowieka chrześcijaństwo (Brzozowski 1910: 100). Tymczasem, zauważał Brzozowski, zaczęła go Z wolna toczyć „choroba zakaźna rewolucji współczesnej” (1970a: 129). Głównym objawem owej „choroby zakaźnej” było wypaczenie pierwotnego założenia o „wierze w ludzkość” (1970a: 129). Socjalizm miał być „powstawaniem, rodzeniem się prawa” (Brzozowski 1910: 101), wobec czego wspominana przez filozofa znajomość „najelementarniejszych pojęć o budowie i życiu nowoczesnych społeczeństw” nie była tylko opcją, lecz koniecznością. To przekonanie patronowało ziałalności Brzozowskiego, gdy wygłaszał „ad majorem Marxi gloriam [pisownia oryginalna - A.S.]" (Brzozowski 1970a: 56) cykl wykładów na Wyższych Kursach Wakacyjnych, które miały „pobudzać słuchaczy do samodzielnych prac i badań, pomóc im do wyrabiania sobie światopoglądu; w rezultacie stworzyć atmosfere, w której dojrzewają umysły wolne" (Uniwersytet Wakacyjny 1905: 5). Forma, jaką zaczął przywdziewać socjalizm podczas zrywów rewolucyjnych, stawała się równie skostniała jak dotychczasowa wiara. By „uważać się za socjaliste” wystarczyło iść za tłumem, samo zrozumienie koncepcji socjalizmu stawało się wtenczas kwestią drugorzędną. Jeżeli to miało być socjalizmem, to - jak pisał autor Płomieni - socjalistą nie był „w takim razie Proudhorn, nie był nim prawdopodobnie Marks, a na pewno Sorel” (Brzozowski 1970a: 313). 
W ujęciu Stanisława Brzozowskiego celem socjalizmu nie było jedynie wyznaczenie ekonomicznego porządku, lecz dokonanie istotnych przeobrażeń w sferze umysłowości. Jednak sposób realizacji socjalistycznych postulatów, jaki miał okazję zaobserwować, postrzegał jako „demoralizowanie klas pracujących” (Brzozowski 1970a: 301), ponieważ bezrefleksyjność ich wcielania nie sprzyjała w żaden sposób „dojrzewaniu umysłów wolnych”. List adresowany do socjalistki, Salomei Perlmutter, ujmuje to stanowisko w niezwykle sugestywny sposób: „Nie chcemy, aby o nas myślano! Chcemy myśleć!” (Brzozowski 1970a: 301), pisał filozof, zwracając tym samym uwage na poznawczą funkcję, jaką pełnić miał socjalizm wobec człowieka nowoczesnego. Pochylenie się nad tą kwestią jest niezwykle ważne w zrozumieniu projektu Brzozowskiego: nie chciał on bowiem, aby socjalizm stał się zaledwie ideą, której człowiek miałby służyć. $\mathrm{Z}$ tego też powodu $\mathrm{z}$ niechęcią odnosił się do pism Engelsa, widząc w nim niepojętnego ucznia Karola Marksa, który - co prawda - przeczytał dzieła mistrza, nie pojął jednak sensu w nich zawartego (Brzozowski 1910: 273-398). Utopijna wizja socjalistycznego społeczeństwa (zob. Bauman 2010), postulowana w pewnym momencie, stanowiła zagrożenie dla nowoczesnego człowieka tym większe, że stwarzała pozór wyzwolenia. O wyzwoleniu mówić można twierdził Brzozowski - tylko wtedy, „gdy nikt za nas naszych losów nie rozstrzyga, gdy tworzenie się prawa może być poddane krytyce przez każdego obywatela" (1910: 102-103).

Tym samym dla Brzozowskiego nie walka polityczna powinna nosić miano socjalizmu, lecz „głęboki, świadomy proces kulturalny, przetwarzający, przekształcający człowieka samego, stwarzający nowy typ człowieka” (1910: 102), który skutkował jego regeneracją (Walicki 1983: 290). „Dojrzewanie umysłów” nie dokonywało się w „historycznej próżni”. By pojąć sedno myśli Brzozowskiego, niezbędne jest zarysowanie dwóch typów społeczeństw: religijno-wojskowego i historyczno-obyczajowego (1910: 281). To rozróżnienie pochodzi z nieco późniejszego okresu twórczości pisarza, jednak wyrażoną w nim treść zasadniczą odnaleźć można w drukach pochodzących z wczesnego etapu „dziejów pewnego umysłu" (zob. Brzozowski 1988). Linię demarkacyjną pomiędzy tymi typami tworzy rodzaj świadomości społecznej. Społeczeństwo religijno-wojskowe ujmowało świat jako gotowy, zastany i niezależny od człowieka, tymczasem społeczeństwo historyczno-obyczajowe - z którym Brzozowski wiązał nowoczesność - odwołuje się do świata w akcie kreacji, stwarzanego. Nie poszukuje ono umocowania w prawie już stworzonym, lecz samo je tworzy w oparciu o historyczno-obyczajową ciągłość i z tego fundamentu - trwalszego niż dogmaty religijne - wyprowadza swe podstawy, tym samym zabezpieczając swoje istnienie w sposób trwały (Brzozowski 1910: 281-282).

W świetle przedstawionych analiz można zatem stwierdzić, że socjalizm $\mathrm{w}$ ujęciu Brzozowskiego silnie łączył się z działaniem nostalgii prospektywnej. Stworzona przez niego koncepcja wypływała bowiem z lęku przed nowoczesnością i była zarówno wyrazem prób reanimacji poczucia bezpieczeństwa wypływającego z porządku, jak i umocowaniem owego porządku na fundamentach 
trwalszych niż niezależne od człowieka prawa religijne. „Wszystkie nowoczesne sprawy i zagadnienia prowadzą mię dziś wstecz” - napisze w jednym z listów (Brzozowski 197ob: 494), gdyż ciągłość historyczno-obyczajową dostrzec można jedynie zerkając w przeszłość. Na jej gruncie tworzy się przyszłość, bez niej zaś człowiek staje się „duszą bez treści, obojętną, niebezpieczną i szkodliwą” (1910: 225). Postulowany przez Brzozowskiego socjalizm był zatem projektem wypływającym z czasu minionego, wyzbytym jednak resentymentu, ponieważ za jego sprawą resuscytował utracone poczucie całościowości, wspólnotowości i bezpieczeństwa. Rekonstrukcja mechanizmów, które legły u podstaw socjalizmu na początku XX w., pozwala zrozumieć jego żywotność również i dzisiaj. Był on w istocie ostatnią wielką narracją scalającą pofragmentowany świat. „Czekamy, szukamy, wspominamy” (Brzozowski 1970a: 104) - oto opis świata nowoczesnego sformułowany przez Brzozowskiego przeszło 100 lat temu, który również i dziś pozostaje aktualny.

\section{BIBLIOGRAFIA}

Bauman, Z. (2010). Socjalizm. Utopia w działaniu (przeł. M. Bogdan). Warszawa: Wydawnictwo Krytyki Politycznej.

Bauman, Z. (2018). Retropia. Jak rządzi nami przeszłość (przeł. K. Lebek). Warszawa: Wydawnictwo Naukowe PWN.

Bell, D. (1998). Kulturowe sprzeczności kapitalizmu (przeł. S. Amsterdamski). Warszawa: Wydawnictwo Naukowe PWN.

Berman, M. (2006). „Wszystko, co stałe, rozptywa się w powietrzu”. Rzecz o doświadczeniu nowoczesności (przeł. M. Szuster). Kraków: Towarzystwo Autorów i Wydawców Prac Naukowych Universitas.

Boym, S. (2001). Nostalgia, Moscow Style. Harvard Design Magazine, 13, 75-83.

Boym, S. (2019). Nostalgia jako źródło cierpień. Ruch Literacki, 6o(1), 99-112. doi: 10.24425/ rl.2018.124791.

Brzozowski, S. (1906). Kilka uwag o zadaniach młodzieży socyalistycznej. Promień. Pismo Polskiej Młodzieży Socyalistycznej, 8(8-10), 179-200.

Brzozowski, S. (1910). Idee. Wstęp do filozofii dojrzałości dziejowej. Lwów: Księgarnia Polska B. Połonieckiego.

Brzozowski, S. (1912). Głosy wśród nocy. Studya nad przesileniem romantycznem kultury europejskiej (red. O. Ortwin). Lwów: Ksieggarnia Polska B. Połonieckiego.

Brzozowski, S. (1913). Pamiętnik (red. O. Ortwin). Lwów: Księgarnia Polska B. Połonieckiego.

Brzozowski, S. (1970a). Listy (T. 1). Kraków: Wydawnictwo Literackie.

Brzozowski, S. (1970b). Listy (T. 2). Kraków: Wydawnictwo Literackie.

Brzozowski, S. (1988). Wczesne prace krytyczne. Warszawa: Państwowy Instytut Wydawniczy.

Burek, T. (1972). Dramat wielkiej krytyki. Teksty, 2, 97-112.

Burszta, W. J. (1997). Nostalgia i mit. W: E. Domańska (red.), Historia. O jeden świat za daleko? (s. 119-130). Poznań: Instytut Historii UAM.

Compagnon, A. (2005). Antynowocześni (przeł. M. Warchala). Europa. Tygodnik Idei, 43, 15-31. 
Czapliński, P. (1999). Wznoszenie biografii. Proza polska lat dziewięćdziesiątych w poszukiwaniu utraconego czasu. Teksty Drugie, 56(3), 55-76.

Goethe, W. J. (1926). Faust (przeł. E. Zegadłowicz). Wadowice: Franciszek Foltin.

Kodisowa, J. (1903). Znaczenie kulturalne filozofii czystego doświadczenia. Przeglad Filozoficzny, 6(4), 380-398.

Leszczyński, A. (2020). Ludowa historia Polski. Historia wyzysku i oporu. Mitologia panowania. Warszawa: Wydawnictwo W.A.B.

Markowski, M. (2007). Polska literatura nowoczesna. Leśmian, Schulz, Witkacy. Kraków: Towarzystwo Autorów i Wydawców Prac Naukowych Universitas.

Marks, K., Engels, F. (1981). Manifest partii komunistycznej. W: K. Marks, F. Engels, Dzieła wybrane (T. 1). Warszawa: Książka i Wiedza.

Mencwel, A. (1988). Między „nową sztuką” a „społecznym ideałem”. Krytyczna młodość Brzozowskiego. W: S. Brzozowski, Wczesne prace krytyczne (s. 5-51). Warszawa: Państwowy Instytut Wydawniczy.

Mencwel, A. (2014). Stanisław Brzozowski. Postawa krytyczna. Warszawa: Wydawnictwo Krytyki Politycznej.

Nietzsche, F. (2001). Poza dobrem i złem (przeł. G. Sowiński). Kraków: Wydawnictwo A.

Ortwin, O. (1912). Przedmowa. W: S. Brzozowski, Głosy wśród nocy. Studya nad przesileniem romantycznem kultury europejskiej. Lwów: Księgarnia Polska B. Połonieckiego.

Rams, P. (2017). Między historią a biografią. Pamiętnik Literacki, 108(1), 23-48.

Siwor, D. (2019). Tropy mitu i rytuału. O polskiej prozie wspótczesnej - nie tylko najnowszej. Kraków: Wydawnictwo Uniwersytetu Jagiellońskiego.

Uniwersytet Wakacyjny (1905, 22 czerwca). Naprzód, s. 5.

Urbanowski, M. (2017). Stanisław Brzozowski. Nowoczesność. Łódź: Wydawnictwo Uniwersytetu Łódzkiego.

Walicki, A. (1983). Polska, Rosja, marksizm. Studia z dziejów marksizmu i jego recepcji. Kraków: Książka i Wiedza.

Walicki, A. (1989). Stanisław Brzozowski and the Polish Beginnings of "Western Marxism". Oxford: Clarendon Press.

Walicki, A. (2011). Stanisław Brzozowski. Drogi myśli. Kraków: Towarzystwo Autorów i Wydawców Prac Naukowych Universitas.

Wyka, M. (2012). Czytanie Brzozowskiego. Kraków: Towarzystwo Autorów i Wydawców Prac Naukowych Universitas.

Zaleski, M. (1996). Formy pamięci. O przedstawianiu przeszłości w polskiej literaturze współczesnej. Łódź: Instytut Badań Literackich PAN. 